With a view to learning what becomes of the winter gnats during inclement weather I frequently jotted down, when the flies were upon the wing, the temperature of the air in the places of their resort, the time of the day, and any peculiarity notice. able in the flight of the insects. Upon other occasions, at corresponding periods of the day, when the weather was colder and no gnats could be seen anywhere, I made similar entries of the temperature prevailing in their usual playgrounds. The instrument employed was a Casella's pocket-thermometer mounted in ebonite, graduated upon the stem at intervals of every two degrees, and duly compared with a standard.

From the notes thus obtained, which need not be quoted in detail, it appears that the flight of Trichocera varies in style with the temperature, and, as a general rule, is altogether discontinued when the cold exceeds $36^{\circ} \mathrm{F}$. Once indeed I saw a gnat flying when the thermometer stood at $34^{\circ} .5 \mathrm{~F}$., but there was reason for suspecting that it had just been startled out of the hedge by a passing carriage. When such low readings as these are obtained the insects do not congregate, but fly singly with a heavy drowsy flight, as though impelled by business rather than pleasure; and very few venture to show themselves upon the wing at all. At temperatures of $38^{\circ}$ to $42^{\circ} \mathrm{F}$. they may be seen occasionally flying steadily in places sheltered from wind; and when a warmth of $45^{\circ} \mathrm{F}$., or more, is attained, they throng together and dance for joy. These particulars, by the way, need not prompt meteorologists to do something with their phenolo. gical tables by entering in them "Trichocera flying" every calm winter's afternoon if the temperature exceeds $40^{\circ} \mathrm{F}$, with out troubling themselves to go out of doors and look after the gnats.

It was some time before I succeeded in tracing Trichocera to the places where it, seeks repose after its gambols and whiles away periods of weather too cold or boisterous for excursions abroad. The flies may be seen sometimes at rest upon fences, with their legs stretched out flat, and it appeared probable that they took refuge in the hedges somewhere. A very favourite harbourage of theirs however seems to be the under side of boards and stones frequented by woodlice and earthworms They stand back downwards on the wood or stone, not upon the earth below; and although the specimens found in such situations are mostly females who have gone there to lay eggs, I have once or twice noticed males taking shelter in similar places. Beneath a single flower-pot saucer standing upon damp earth, and eight inches across the bottom, I have counted as many as ten females at once; an individual gnat dislodged crept back underneath it again; but the site became dry, and they forsook it. The wonder was how they managed to enter so shallow a crevice in the first instance. The haunts of the isopod, Trichoniscus pusillus, are not too damp for them; but in frosty weather they are apt to take shelter under any dry pieces of wood lying loosely upon the ground. It is obvious that flies with such habits as these cannot fail to be snowed up in great numbers at the first fall; and when the frost is over, having been securely protected from extreme cold, they are ready to take wing again as soon as the snow has melted sufficiently to admit of their creeping forth. Hence, though the temperature may be relatively mild directly after a snowstorm, no gnats are likely to be seen flying until the snow has largely disappeared, when Trichocera will become common. Similarly after frost without snow, when the thaw sets in the flies will probably not issue from their retirement immediately, but will rest quietly until the change of temperature has had time to reach them in their lurking-places, whatever may be the warmth of the outer air meanwhile. Perhaps this is the cause of so few winter gnats being seen in the mornings early in the year; but whether it be so or not, the other foregoing surmises harmonise well with my observations.

The maximum of cold to which winter gnats can be exposed without fatal conšquences has not yet been ascertained.

Chepstow Road, Croydon, April

A. E. EATON

\section{Australian Plants in India}

IN NATURE, vol. xxiii. p. 370, some remarks are made (with reference to Mr. Wallace's observations in "Island Life") regarding the apparent inability of Australian plants to become naturalised in the northern hemisphere. It may therefore be interesting to you and to $\mathrm{Mr}$. Wallace to learn of some striking exceptions to this rule in the case of Australian plants which have been introduced on the Nilgiri platean in Southern India, at elevations ranging from about 5500 to nearly 8000 feet above sea-level. Acacias and Eucalypti in particular have found a congenial home in this region, and visitors from Australia who have secn them say that they appear even more vigorous than in their native soil. Hundreds of acres of Eucalyptus Globulus and of Acacia melanoxylon and $A$. dealbata have been planted by Government as firewood reserves, and the trees have grown up splendidly. The only drawback to the success of the experiment has been that the Acacia melanoxylon has been greatly injured by Loranthaceous parasites. In fact this species will apparently in course of time be exterminated by these indigenous pests. Besides Eucalyftus Globulus the following species of the genus have also been introduced, and thrive well : $-E$. sideroxylon, $E$. obliqua, $E$. fissilis, $E$. rostrata, $E$. viminalis, $E$. amygdalina, and $E$. perfoliata. In addition to the two species of Acacia already mentioned, the following have also been added to the list of healthy growing exotics on the Nilgiris, viz. A. pycnantha, $A$. salicina, $A$. longifolia, $A$. decurrens, $A$. cultriformis, $A$. elata, and others, might also be enumerated. As regards other Australian plants on these hills we have Hakea, Banksia, Myoporum, Kunzea, Tristania, Pittosporum, Beaufortia, \&c. In short there is a very considerable Australian flora flourishing on the "Blue Mountains" of Madras, and so extensively have the trees been planted out about the principal stations that they have given quite a new character to the scenery. Some of the acacias have a considerable resemblance in shape and colour to the Scotch fir, and this likeness has, to some visitors, added a fresh charm to the beauties of the scenery. Madras, March I5

\section{The Tide Predicter}

WITH regard to the letter of Sir William Thomson in NATURE, vol, xxiii. p. 482, respecting the above instrument, I may say that the Tide Predicter which I have planned and designed for the prediction of Indian tides owes its development, not to the British Association Tide Predicter, but to a complete two-consponent working model made by me in the spring of 1873 . This model was made before the British Association instrument was designed.

It was on the express recommendation of the Surveyor-General and Superintendent of the Great Trigonometrical Survey of India that I was invited to plan and undertake the construction of the instrument, and I was left absolutely unfettered in my choice of mechanicians to carry out the work. My connection with the instrument is clearly explained in the official prefaces to the Tide Tables for Indian Ports, I88r, published by authority of the Secretary of State for India in Council. I may point out that my paper upon this instrument (Proceedings Roy. Soc., No. 197, 1879) was written at the desire of Sir William Thomson, to whom it was first submitted, and by whom it was entirely approved and originally communicated. He was also present at the meeting of the Royal Society when the paper was read, and never expressed the least objection to any of its contents. In that paper credit is given to him for the improved slide, which he, with Prof. James Thomson's assistance, had devised for an harmonic analyser, and also to Mr. A. Légé for the admirable plan of the wheel-gearing.

3, Verulam Buildings, Gray's Inn, W.C., March 26

\section{"The Oldest Picture in the World"}

IN Mr. Loftie's "Ride in Egypt" is a woodcut (p. 209) of what is called "the oldest picture in the world," a fresco from a tomb at Maydoom, now in the museum at Boolak, wherein are represented six "pasturing geese." Two of these are undoubtedly Anser allifrons, two, probably $A$. ferus or $A$. segetum, and the other two seem to be the rare $A$. ruficollis, from Northern Asia. I should be greatly obliged to any one who would let me see a coloured copy of this picture, that I might be assured as to my determination of the figures. Mr. Dresser, in his excellent "Birds of Europe," mentions his having received a specimen of $A$. ruficollis sent him from Alexandria by the late Mr. Stafford Allen. Otherwise its appearance in Egypt seems to have been hitherto unrecorded.

Magdalene College, Cambridge, April Io

\section{Probably New Variable Star}

ON January 22, 1879 , I observed near $\mathrm{O}^{2}$ Canis, a very remarkable double star, with one component a fiery red 8.5 